\title{
ГРАМАТИЧНЕ ЗНАЧЕННЯ ОДНИНИ: МОДЕЛЮВАННЯ ОЦІННИХ СМИСЛІВ
}

У статті проаналізовано особливості моделювання граматичних ігрем для вираження оцінних смислів на основі актуалізації граматичного значення однини (однина експресивно-оцінна, однина агресивна, однина пошанна), схарактеризовано спеиифіку іх уживання в сучасному мовленні. Досліджувані одиниці мовної гри моделює транспоноване вживання числових форм та креативне формотворення. Висвітлено особливості вживання форм однини як засобів тропеїстики в українській мові, описано дифузні зони взаємодії граматичної й лексичної семантики в процесі моделювання тропів.

Ключові слова: однина, граматична ігрема, оцінка, тропеїстика, українська мова.

Khaliman O. V. The Grammatical Meaning of the Singular: Modeling of Evaluative Meanings. The features of grammatical ludic means modeling are analyzed in the article to express evaluative meanings based on actualization of grammatical meaning of singular.

1. Singular expressive evaluative: a) transposing into the area of use of opposition categorical form (grammatical metaphor), singular form acquires negative shades of disdain. Studying plurality in singular, the speaker belittles, casts doubt on the importance of the nominees, objects or phenomena, thus ensures the creation of corresponding connotations; $b$ ) the modeling of lexico-grammatical oxymoron (creative formation based on overcoming incompatibility of grammatical meaning of form and lexical meaning of a word) is also related to the creative implementation of the category of number. Formation of a lexico-grammatical oxymoron involving singular forms is based on the conflict of meanings of plurality / singularity. Oxymoronic forms are used as one person / item nomination, and the totality of persons / objects. The singular forms formed by plurativity, are marked by the occassionality that expresses speech and enhances pragmatic effect. Nominating the plural form of the singular, the speaker expresses disdain for the marked denotations, ignores them, grammatical singularity reduces the significance of the real power that provides appearance of negative shades of contempt.

2. Singular aggressive. As opposed to plural respectful singular aggressive is allocated - deliberate appeal to the interlocutor in the singular in a situation where it would be more appropriate to use the plural form (grammatical metaphor) that is carried out for the purpose of expressing negative estimation. Breaking the rules of etiquette, the speaker manipulates grammatical means, which forms a grammatical ludic means: the singular negates the reverence, is the means of expression of negative attitude to the interlocutor. 
3. Singular respectful. You (singular)-addressing, used instead of You (plural)models as for a person (grammatical metaphor) of older age and higher status that does not prejudge the communication deviance, involves the addressing of respect, honour, appreciation of outstanding personalities. Such discourse is full of revelry, a positive estimation of their activities and awareness of their importance within a community.

Key words: singular, grammatical ludic means, tropes, Ukrainian language.

\section{Вступ}

Для номінації й характеристики елементів довкілля комуніканти креативно оперують мовними знаками, при цьому часто виникає семантична двоплановість між формою однієї одиниці й змістом іншої, що грунтується на асоціативних зв'язках. Під час вторинної номінації денотативну частину значення доповнює конотативна. Такі перенесення є основою тропів - слів, уживаних у переносному значенні для характеристики певного явища за допомогою вторинних смислових значень. У процесі моделювання окремих тропів спостерігаємо актуалізацію граматичних засобів, що супроводжується породженням оцінних відтінків значення. Інколи простежуємо синкретизм засобів тропеїстики, що посилює прагматичний ефект.

Особливості моделювання тропів для вираження оцінних відтінків значення й раніше були в полі зору дослідників. Мовознавці характеризували здатність тропів виконувати оцінну функцію загалом (Л. Дейна), а також зосереджувалися на специфіці окремих із них: способах репрезентації оцінної семантики в мовленнєвому акті іронії (О. Калита), функційно-прагматичних можливостях оксиморонів в аспекті вираження емоцій (В. Сухенко), маніпулятивній та оцінній функціях евфемізмів і дисфемізмів (І. Решетарова) та ін. Граматичні особливості в зазначеному ракурсі ставали об'єктом аналізу значно рідше - сучасні мовознавці досліджували окремі аксіологічні аспекти граматичної метафори (Є. Шендельс, I. Назаренко, Л. Наконечна).

Мета цієї розвідки - схарактеризувати механізми моделювання граматичних ігрем для вираження оцінних смислів, що породжуються на основі актуалізації граматичного значення однини. Зазначена мета передбачає розв'язання таких завдань: 1) на прикладі граматичного значення однини описати способи моделювання граматичних ігрем для вираження значення оцінки; 2) висвітлити особливості вживання форм однини як засобів створення тропеїстики. 


\section{Методи та методики дослідження}

У процесі дослідження було застосовано метод спостереження, описовий метод (прийоми внутрішньої й зовнішньої інтерпретації). Для дослідження оцінної семантики використано методи компонентного, контекстуального, порівняльного аналізів; методи вибірки для відбору фактичного матеріалу.

\section{Результати та дискусії}

Граматичне значення однини, як засвідчує проведений аналіз, бере участь у таких механізмах породження оцінних значень: 1) однина експресивно-оцінна; 2) однина агресивна; 3) однина пошанна. Крім того, досліджувані одиниці функціюють як засоби тропеїстики.

\section{1. Однина експресивно-оцінна.}

а) у сучасній українській мові спостерігаємо транспоноване вживання форм однини замість множини, що стає основою граматичної метабори.

Граматична метафора, як відомо, виникає внаслідок перенесення граматичної форми з одного виду зв'язків на інший (див. детальний опис Халіман, 2009). В основі механізму граматичної метафори, як і метафори лексичної, - образність, контрастність та прийом перенесення (транспозиція граматичної форми в нове синтаксичне оточення, у сферу вживання іншої форми тієї самої системи опозицій), але при цьому граматична (морфологічна) метафора, як слушно наголошує I. Назаренко, характеризується зв'язком із синтаксичним рівнем (Назаренко, 2009: 6), оскільки транспозиційні можливості морфологічної одиниці реалізуються в контексті.

Хоча метафорична сила класифікаційних категорій найбільша й найяскравіша завдяки їхньому тісному зв'язку з лексичним значенням (у створенні метафори бере участь і лексичне, і граматичне значення) (Шендельс, 1972), проте, як демонструє аналіз фактичного матеріалу, у процесі метафоризації елементів словозмінних категорій граматичну метафору може доповнювати метафора лексична чи інші тропи, змодельовані на лексичному рівні, що підвищує образність.

Зображувальна роль форм однини, на думку О. Єфимова, більш значна порівняно з множиною: вони часто вживаються замість форм множини, супроводжуючись появою додаткових семантичних відтінків та експресивності (Ефимов, 1961: 317). 3 останнім не можемо 
погодитись, оскільки зібраний фактичний матеріал надав обмежену кількість прикладів таких уживань (у порівнянні з продуктивними моделями за участю форм множини), про що йтиметься далі.

Непродуктивність цього типу транспозиції засвідчують також інші дослідники. Хоча письменники та журналісти й використовують словоформи однини в збірному значенні в ролі знака розмовності в художньому та публіцистичному діалозі, уживання такої моделі, зауважує О. Земська, є нехарактерним для розмовного мовлення. Такі випадки поодинокі (наводимо ілюстративний матеріал, поданий у роботах дослідників-русистів, у перекладі українською; збереження семантики засвідчує актуальність зазначених тверджень і для української мови): ...у тебе завтра ще один день і власне все. Студенту завжди одного дня не вистачає; Ну, восени в нас молодий викладач у колгоспі (Русская разговорная речь..., 1983: 79). Словоформи однини в збірній функції виражають «експресію образної конкретності». Погодимося з твердженням, що форма однини (на позначення одного предмета) легко замінюється формою множини, однак зворотна заміна, якщо номінують справді множину предметів, викликає в мовця труднощі (Русская разговорная речь..., 1983: 74).

Використання форми однини в збірному значенні замість множини Т. Радбіль уважає менш аномальною тенденцією, ніж протилежну заміну числових форм, «проте й тут є своя допустима межа, за якою явище стає аномальним більшою мірою» (Радбиль, 2012: 238). Зокрема, дослідник наводить приклади з творчості Д. Хармса, який, на його думку, «доводить до абсурду цю модель, уживаючи в однині замість множини слово зуб, що осмислюється як множинність, напр. (рос.): Полковник ручкой помахал / и вышел, зубом [зубами] скрежеща. Ця модель «має свої відповідники в розмовному мовленні, звідки завдяки явній експресії й узагальнювально-символічному характеру, перекочувала в публіцистику й у 'мову революційних гасел'» (Радбиль, 2012: 238).

Прийом використання форм однини на позначення множинності О. Земська називає одниною експресивною, що створюється завдяки контрасту між формою й позначуваною дійсністю, порівн. (у перекладі укр.): А. Ти працюєи? А щзо ти там робиш? Л. Пробірку мию; А. Я йдудо Люди допомагати пробірку мити; А. А чим там годують? Б. Сосиску дають із зеленим горочком; А. Ти що? Б. Йду зуб чистит; 
(молодій матері) Пелюшку випрала? (Русская разговорная речь..., 1983: 136). «Така фігуральна однина передає в художньому мовленні відтінок зневаги, сарказму» (Серажим, 1996: 4-5), відзначається значним експресивним забарвленням.

Метафоризовані граматичні форми однини, що функціюють як засоби моделювання аксіологічних відтінків, називаємо одниною експресивно-оцінною. Транспонуючись у сферу вживання опозиційної категорійної форми, форма однини набуває негативних відтінків зневаги, іронії. Розмірковуючи про множинність в однині, мовець применшує, ставить під сумнів важливість номінованих осіб, предметів чи явищ, чим і забезпечує появу конотації. Художнє применшення величини, сили, значення зображуваного предмета чи явища, як відомо, забезпечує літота - різновид метонімії (протилежний за значенням гіперболі). Отже, у цьому разі спостерігаємо синкретизм засобів тропеїстики: метафора відтворюється на граматичному рівні, літота - на лексико-семантичному;

б) $з$ креативною реалізацією категорії числа також пов'язане моделювання тексико-граматичного оксиморона. Це таке вживання мовних одиниць, коли під час формотворення спостерігаємо несумісність граматичного значення форми й лексичного значення слова. Лексико-граматичні оксиморони моделюються на основі лексикограматичної асиметрії. У процесі функціювання лексеми в невластивій для неї словоформі породжується ефект граматичної образності. Така суперечність між лексичними й граматичними семами досить яскраво демонструється в морфології під час творення граматичних ігрем.

Моделювання лексико-граматичного оксиморона за участю форм однини грунтується на конфліктності смислів плюральність / однинність. Форми іменників pluralia tantum, що характеризуються «певною видозміною в семантиці й емоційному забарвленні» (Дудик, 2005: 14) у формах однини, як відомо, містять потенціал актуалізації додаткових смислових відтінків, напр.: Із цією кадрою одні проблеми... (у розмовно-побутовому мовленні - із зниженим, іронічним відтінком).

Досліджуючи в художньому мовленні таке вживання у формах однини іменників, що не відповідає сучасній мовній нормі, І. Голуб відносить їх до граматичних архаїзмів, зважаючи на низьку частотність 
їхнього використання, напр. (у перекладі укр.): Пролунав сміх і аплодисмент, хоча й нечисленний (Голуб, 2001: 229). Як рідкісне явище в сучасній російській мові Г. Хайрутдинова також засвідчує спроби індивідуально-авторського розширення парадигми числа шляхом утворення форми однини від іменників pluralia tantum, напр. (рос.): Разве что браконьеришки осенями запрутся в глубинную таежную дебрю, из которой и сейчас еще тянуло холодом и мшелой, седой дикостью. (В. Астафьев) (Хайдутдинова, 2009: 26).

Уживання форм однини моделює граматичну ігрему: негативну оцінку позначуваного об'єкта забезпечує контраст між формою (граматична форма однини) й позначуваною дійсністю (множинність). Номінуючи множинність формою однини, мовець виражає зневагу до позначуваних денотатів, ігнорує їх, граматична однинність начебто зменшує значущість реальної можинності, що забезпечує появу негативних відтінків зневаги.

У цій моделі лексико-граматичного оксиморона спостерігаємо два різновиди вживання:

1) використання форми однини, утвореної від іменника pluralia tantum, для номінації однієї особи чи предмета (напр., кадра). Слово, що традиційно співвідноситься у свідомості носіїв мови з множинністю, у процесі його граматичного оформлення у формі однини (лексикограматичний оксиморон) сприймається як оказіональне й вербалізує смислові відтінки зневаги. На відміну від уживання в такій функції іменників з повною числовою парадигмою, форми однини, утворені від плюративів, відзначаються оказіональністю, що увиразнює мовлення й підсилює прагматичний ефект.

В українській мові має місце поодиноке функціювання таких форм: П. Глазовий, оповідаючи гумористичну історію про п'яного чоловіка, поряд з формою множини кадри та з іронічно використаною ввічливою формою множини пошанної (- Поклади їx у коляску, А я пройдусь пішки. До відділення вези, Та не дуже їх тряси, Хай не утомляються, - Такі кадри на дорозі Просто не валяються (П. Глазовий)) застосовує експресивно-оцінну форму кадра. Гумористичний ефект та негативну оцінку посилює невідповідність жіночого роду утвореної форми однини та статі номінованої особи;

2) застосування форми однини, утвореної від іменника pluralia tantum, щодо сукупності осіб чи предметів (аплодисмент, алімент, 
мемуар), порівн.: І на щзо цього разу я витрачу ией алімент? (з розм. мовл., іронічно, з негативною вказівкою на малу суму грошей). Вербалізуючи множинність у граматичній формі однини, мовець, як було зазначено, применшує значущість предметів, осіб чи явищ, чим і забезпечує створення відповідної негативної конотації.

У цьому разі спостерігаємо подвійний конфлікт: а) між формою й лексичним наповненням під час утворення мовної одиниці та б) між формою й позначуваними денотатами в процесі ії вживання. У такому типі вживань також простежуємо синкретизм у моделюванні тропів на граматичному (лексико-граматичний оксиморон) та лексико-семантичному (літота) рівнях.

Наявність обмеженої кількості прикладів використання однини експресивно-оцінної засвідчує низьку частотність уживання подібних форм і характеризує досліджуваний механізм як непродуктивний у сучасному українському мовленні.

2. Однина агресивна. Як протиставлення множині пошанній можемо виділити однину агресивну - навмисне звертання до співрозмовника у формі однини в ситуації, де більш доречною була $б$ форма множини, що здійснюється з метою вираження негативної оцінки.

Використання «ти»-звертання в офіційній ситуації спілкування з незнайомим або малознайомим, старшим за віком Ю. Щербініна розглядає як прояв мовленнєвої агресії («образливе спілкування, словесне вираження негативних емоцій, почуттів або намірів в образливій, грубій, неприйнятній у певній мовній ситуації формі» (Щербинина, 2005: 5)), що «веде до порушення гармонії спілкування, провокує заперечення, незадоволення, протест співрозмовника» (Щербинина, 2005: 162). Це засвідчують «негативні емоційні реакції адресата на таке висловлювання (образа, гнів, роздратування й т. ін.) й репліки-відповіді (звинувачення, докір, відмова, вираження протесту, незгоди, образи у відповідь і т. ін.)» (Щербинина, 2005: 7), порівн: I чого ие ти мені тикаєи, мала? Де твоя повага до старших? Хіба тебе иъого не вчили? - Сірий скривився. Мальва йому теж не подобалася. Неприязнь у них була взаємною (Дара Корній).

У комунікації, звісно, можлива й зміна офіційного «Ви» на дружнє «ти» (така «ти»-форма маркує інтимність, використовується в спілкуванні з друзями, коханими, між подружжям і близькою родиною, при звертанні до рівного за становищем і молодшого віком 
(Формановская, 2007: 244)), проте перехід одного чи обох учасників діалогу з увічливого «Ви» до фамільярного «ти» $є$ прагматичним засобом негативного емоційного впливу (Федосюк, 1997: 66-88). Використання такої форми стає «свідченням відсутності поваги, проявом агресії, невихованості, особливо якщо йдеться про ситуації спілкування незнайомих дорослих або звертання начальника до підлеглого з метою підвищення свого соціального статусу й зниження статусу адресата» (Шкіцька, 2011: 401). Отже, перехід з «Ви» на «ти» «може передавати зневажливе ставлення до співрозмовника, маркувати грубість та невихованість, а також бути ознакою близькості й зменшення дистанції між партнерами по інтеракції» (Шкіцька, 2011: 405).

I в тривалих дружніх стосунках, як відомо, іноді зберігається спілкування на «Ви» серед людей середнього та старшого покоління, інтелігентів. У цьому разі з переходом на «ти» також пов'язують утрату шанобливого ставлення до адресата, появу певної фамільярності (Формановская, 2007: 16-17). Недоречне звертання на «ти» «призводить до можливості виникнення напруженості в стосунках», що з'являються через почуття дискомфорту або неспокою індивіда (Фесенко, 2015: 30). Ф. Бацевич визнає, що неправильний вибір числа звертання $є$ сильним чинником, сильнішим за інші помилки: «Іноді звертання на «ти» замість «Ви» може глибше вразити співрозмовника, аніж будь-яка граматична помилка» (Бацевич, 2004: 267). Навмисне використання «ти»-звертання може слугувати й засобом вираження неповаги до співрозмовника, його негативної оцінки.

Вибір між формами другої особи однини / множини, зауважує А. Болотнікова, зумовлений «прагматичними пресупозиціями: а) соціальний статус («вищий», «нижчий», «рівні»); б) ситуація спілкування (офіційна - неофіційна); в) рівень знайомства (знайомі - малознайомі - незнайомі); г) вік («молодший», «старший»)» (Болотнікова, 2018: 110). Недоречний вибір особової форми, як бачимо, спровокований порушеннями цих прагматичних складників, що й спричиняє появу вторинних смислів.

Для вираження мовленнєвої агресії комуніканти застосовують передусім займенник ти (замість Ви), напр.: Ти плюгавий порохобот, заробітчанин, гнида (Степан Хмара до блогера Андрія Полтави; з Інтернет-ресурсів), що супроводжується вираженням негативу до співрозмовника. В авторській картотеці ілюстративного матеріалу, 
до речі, зафіксовано інші приклади, пов'язані з функціюванням займенника ти в мовленні Степана Хмари як негативно оцінного засобу, що можна кваліфікувати як специфіку індивідуального мовлення.

Дослідники також зосереджуються на функціюванні дієслівних імперативних форм, пов'язане з маніпуляцією граматичним значенням числа. У разі вживання в односкладному реченні дієслівного головного члена функцію вираження числової особливості виконує дієслово, напр.: Закрий свою плюгаву морду (Степан Хмара до блогера Андрія Полтави; з Інтернет-ресурсів). У наведеному прикладі імперативна форма демонструє звертання до співрозмовника на 'ти', проте такі моделі мовці використовують і для звертання до групи осіб, що «призводить до різкої зміни, фамільярного огрублення експресії», напр. (рос.): Он идет да поет, / Ветер подпевает; / Сторонись, богачи! / Беднота гуляет! (И. Никитин) (Хайрутдинова, 2009: 26).

На це звертає увагу й Н. Ясакова, зауважуючи, що форму однини мають дієслова наказового способу у військових командах (- He nідxодь! - крикнув він [сотник] у вікно і пустив коротку чергу понад селянські голови (Б. Антоненко-Давидович)), іiі також зустрічаємо у звертанні охоронців до групи ув'язнених ( - Кіниа-ай прогулянку! 3a-axoдb! (Б. Антоненко-Давидович), під час заклику до миттєвої дії, що стосується великої групи осіб (Бий їх, старогородських шевиів! (...) Бий їх, щьб і не наближались до нас. (...) Ганяй їх! Бий їх! (I. Нечуй-Левицький)). Однина в цьому разі, наголошує дослідниця, виражає вищість мовця, залежність адресата мовлення й категоричність наказу (Ясакова, 2009: 180). Такі ознаки комунікантів і тональності мовлення засвідчують негативне ставлення мовця до співрозмовників, що характеризує досліджувану одиницю як засіб вираження відповідної оцінки.

Отже, у протилежність уживанню множини пошанної комуніканти використовують форми однини, що слугує засобом висловлення неповаги, негативної оцінки (однина агресивна). Порушуючи етикетні норми, мовець маніпулює граматичними засобами, що формує граматичну ігрему: форма однини нівелює шанобливість (літота - применшення значущості), яку б виражала більш доречна в конкретній комунікативній ситуації форма множини (граматична метафора - транспоноване вживання форми). Використання «тикання», крім порушення етикету, слугує засобом вираження негативного 
ставлення до співрозмовника, що забезпечує маніпуляція числовими формами.

3. Однина пошанна. Поряд з пошанною множиною, як зауважує О. Пономарів, існує й пошанна однина - «звертання на ти до визначних сучасників та історичних осіб. Такі тексти потребують належного добору мовних засобів, що сприяють створенню піднесеності, урочистості, святобливості» (Пономарів, 2000: 150), порівн.: Будеш, батьку, панувати, Поки живуть люди, Поки сонце з неба сяє, Тебе не забудуть (Т. Шевченко про І. Котляревського).

Відомі і прозові, і поетичні рядки, адресовані Тарасові Шевченку, що містять досліджуваний засіб, напр.: Ти-бо, Тарасе, вчив нас не людей із свого світу згоняти, не городи й села опановувати: ти вчив нас правди, святої, животворящої (П. Куліш); Спочиваєи ти, наш батьку, Тихо в домовині, Та збудила твоя пісня Думки на Вкраїні... Щоб між нами не вгасало Проміння величне, Ти поставив «на сторожі» Слово твоє вічне. Ми, як ти, минати будем Чужії пороги, Орать будем свої ниви, Рідні перелоги (Леся Українка); Ми чуємо тебе, Кобзарю, крізь століття, I голос твій нам душі окриля, Встає в новій красі, забувши лихоліття, Твоя, Тарасе, звільнена земля, У росяні вінки заплетені суцвіття До ніг тобі, титане, кладемо. Ми чуємо тебе, Кобзарю, крізь століття, Тебе своїм сучасником звемо (В. Симоненко).

Tu-звертання, використане замість Ви-моделей щодо особи (граматична метафора - транспоноване вживання форми), старшої за віком і вищої за статусом, що не зумовлює комунікативних девіацій, передбачає адресацію поваги, шаноби, удячності видатним особам (пошанність, гіперболізація). Такий дискурс зазвичай сповнений урочистості, позитивної оцінки їхньої діяльності й констатації їхньої важливості в межах певної спільноти. Досліджувана модель є складником етикетних формул і відображає традиції українського мовлення. Цей засіб є доречним лише в обмежених контекстах, оскільки більш поширеним $є$ перехід до $m u$-звертання, що $є$ проявом мовної агресії й супроводжується негативною оцінкою адресата.

\section{Висновки}

Отже, як бачимо, у процесі моделювання тропів за участю граматичних форм однини можна спостерігати такі дифузні зони взаємодії граматичної й лексичної семантики, що відзначається появою 
аксіологічних смислів: 1) граматична метафора + літота (однина експресивно-оцінна, однина агресивна); 2) лексико-граматичний оксиморон + літота (однина експресивно-оцінна); 3) метафора + гіпербола (однина пошанна).

Основне категорійне значення кожної грамеми в певних контекстах може ставати переносним, модифікуватися й цим призводити до граматичної багатозначності, що й простежуємо на прикладі граматичного значення однини. Креативне формотворення також сприяє розширенню функцій досліджуваних одиниць. Найменування, що виникають унаслідок таких модифікацій, свідчать про багатогранність мовного знака й сприяють розвитку мовної системи.

Зібраний фактичний матеріал надав обмежену кількість прикладів використання однини в оцінних функціях (серед виділених механізмів найбільш поширеною $є$ однина агресивна), що підтверджує наведену тезу щодо низької частотності вживання таких форм і характеризує аналізовані механізми як непродуктивні в сучасному мовленні українців.

Здавалося б, розмаїття первинних і вторинних значень форм однини зумовлює характеристику таких одиниць як засобів високого комунікативного рангу, однак саме така поліфункційність може ставати й основою для комунікативних девіацій, оскільки засіб, використаний мовцем 3 певною комунікативною метою, може бути потрактований співрозмовником в іншому варіанті значення відповідної одиниці, що залежить від його особистого комунікативного досвіду. Тому доречне застосування досліджуваних засобів потребує високої мовної, комунікативної й прагматичної компетентностей співрозмовників.

У перспективі плануємо аналіз інших граматичних одиниць української мови у виокремленому ракурсі для створення цілісної теорії граматики оцінки.

\section{ЛІТЕРАТУРА}

1. Бацевич Ф. С. Основи комунікативної лінгвістики: підруч. Київ, 2004. 342 с. 2. Болотнікова А. П. Граматичні індикатори вираження категорії ввічливості в українській мові: дис. ... канд. філол. наук: 10.02.01. Запоріжжя, 2018. 3. Голуб И. Б. Стилистика русского языка. 3-е изд., испр. Москва, 2001. 448 с. 4. Дудик П. С. Стилістика української мови: навч. посіб. Київ, 2005. 368 с. 5. Ефимов А. И. Стилистика художественной речи. 2-е узд., доп. и перераб. Москва, 1961. 519 с. 6. Назаренко I. О. 
Транспозиція граматичних форм іменних частин мови: функціонально-семантичний аспект: автореф. дис. ... канд. філол. наук: 10.02.01. Запоріжжя, 2009. 21 с. 7. Пономарів О. Д. Стилістика сучасної української мови: підруч. 3-тє вид., перероб. і доп. Тернопіль, 2000. 248 с. 8. Радбиль Т. Б. Языковые аномалии в художественном тексте: Андрей Платонов и другие: моногр. Москва: Флинта, 2012. 322 с. 9. Русская разговорная речь. Фонетика. Морфология. Лексика. Жест / ред. Е. А. Земская. Москва, 1983. 239 с. 10. Серажим К. С. Морфологічні засоби стилістики: навч. посіб. з курсу «Практична стилістика сучасної української мови». Київ, 1996. 60 с. 11. Федосюк М. Ю. Исследование средств речевого воздействия и теория жанров речи. Жанры речи. Саратов: Колледж, 1997. С. 66-87. 12. Фесенко I. Перехід від однини до множини при звертанні до особи. 2-е вид., випр. і доп. Київ, 2015. 184 с. 13. Формановская Н. И. Речевое взаимодействие: коммуникация и прагматика. Москва, 2007. 478 с. 14. Хайрутдинова Г. А. Эстетические ресурсы морфологических средств русского языка: автореф. дис. ... докт. филол. наук: 10.02.01. Казань, 2009. 45 с. 15. Халіман О. В. Граматична метафоризація як механізм творення оцінних значень (на матеріалі числових форм множини). Вісн. Дніпропетр. ун-ту. Серія «Мовознавство» / відп. ред. Т. С. Пристайко. Дніпропетровськ: Вид-во Дніпропетр. держ. ун-ту, 2009. № 11. Вип. 15. Т. 2. С. 155-159. 16. Шендельс Е. И. Грамматическая метафора. НДВШ: Филол. науки. 1972. № 3. С. 48-57. 17. Шкіцька І. Ю. Займенники «ти»-«Ви» в маніпулятивній стратегії позитиву. Актуальні проблеми слов'янської філологіі. Сер. «Лінгвістика і літературознавство»: міжвуз. зб. наук. ст. 2011. Вип. XXIV. Ч. 1. С. 400-408. 18. Щербинина Ю. В. Русский язык: Речевая агрессия и пути ее преодоления: учеб. пособие. Москва, 2004. 224 с. 19. Ясакова Н. Ю. Особливості взаємодії категорійної семантики персональності та квантитативності. Наук. часопис Нац. пед. ун-ту ім. М. П. Драгоманова. Сер. 10. «Проблеми граматики і лексикології української мови»: зб. наук. пр. / відп. редактор М. Я. Плющ. Київ, 2009. Вип. 5. С. 178-182.

\section{References}

1. Batsevych, F. S. (2004). Osnovy komunikatyvnoi linhvistyky [Fundamentals of Communicative Linguistics]. Kyiv: Vyd. tsentr «Akademiia» [in Ukrainian]. 2. Bolotnikova, A. P. (2018). Hramatychni indykatory vyrazhennia katehorii vvichlyvosti v ukrainskii movi [Grammatical indicators of politeness in the Ukrainian language]. Candidate's thesis. Zaporizhzhia: ZDU [in Ukrainian]. 3. Golub, I. B. (2001). Stilistika russkogo yazyka [Stylistics of the Russian language]. Moskva: Rol'f [in Russian]. 4. Dudyk, P. S. (2005). Stylistyka ukrainskoi movy [Stylistics of the Ukrainian language]. Kyiv: Vyd. tsentr "Akademiia» [in Ukrainian]. 5. Efimov, A. I. (1961). Stilistika xudozhestvennoj rechi [Artistic stylistics]. Moskva: Izd-vo Moskov un-ta [in Russian]. 6. Nazarenko, I. O. (2009). Transpozytsiia hramatychnykh form imennykh chastyn movy: funktsionalno-semantychnyi aspekt [Transposition of grammatical forms of nouns of language: functional-semantic aspect]. Extended abstract of candidate's thesis. Zaporizhzhia: ZDU [in Ukrainian]. 7. Ponomariv, O. D. (2000). Stylistyka suchasnoi ukrainskoi movy [Stylistics of modern Ukrainian language]. Ternopil: Navch. knyha - Bohdan [in Ukrainian]. 8. Radbil', T. B. (2012). Yazykovye anomalii $v$ xudozhestvennom tekste: Andrej Platonov $i$ drugie [Linguistic anomalies in a literary text: Andrei Platonov and others]. Moskva: Flinta [in Russian]. 9. Zemskaya, E. A. (Eds.). (1983). Russkaya razgovornaya rech'. Fonetika. Morfologiya. Leksika. Zhest [Russian 
colloquial speech. Phonetics. Morphology. Vocabulary. Gesture]. Moskva: Nauka [in Russian]. 10. Serazhym, K. S. (1996). Morfolohichni zasoby stylistyky [Morphological means of stylistics]. Kyiv: Kyiv. un-t im. T. Shevchenka [in Ukrainian]. 11. Fedosyuk, M. Yu. (1997) Issledovanie sredstv rechevogo vozdejstviya i teoriya zhanrov rechi [The study of means of speech exposure and the theory of speech genres]. Zhanry rechi-Speech Genres, (pp. 66-87). Saratov: Kolledzh. [in Russian]. 12. Fesenko, I. (2015) Perekhid vid odnyny do mnozhyny pry zvertanni do osoby [The transition from singular to plural when addressing a person]. Kyiv: Inzh.-vyrob. tsentr ALKON [in Ukrainian]. 13. Formanovskaya, N. I. (2007). Rechevoe vzaimodejstvie: kommunikaciya i pragmatika [Speech Interaction: Communication and Pragmatics]. Moskva: IKAR [in Russian]. 14. Xajrutdinova, G. A. (2009). Essteticheskie resursy morfologicheskix sredstv russkogo yazyka [Aesthetic resources of morphological means of the Russian language]. Extended abstract of Doctor's thesis. Kazan': KGU [in Russian]. 15. Khaliman, O. V. (2009). Hramatychna metaforyzatsiia yak mekhanizm tvorennia otsinnykh znachen (na materiali chyslovykh form mnozhyny) [Grammatical Metaphorization as a mechanism of creation of estimating values (on the material of the numerical forms of the plural)]. Visn. Dnipropetr. un-tu - Bulletin of Dnipropetrovsk Univ. Seriia «Movoznavstvo». T. S. Prystaiko (ed.). Dnipropetrovsk: Vyd-vo Dnipropetr. derzh. un-tu, 11, Issue. 15, Vol. 2, 155-159 [in Ukrainian]. 16. Shendel's, E. I. (1972). Grammaticheskaya metafora [A grammatical metaphor]. NDVSh: Filol. nauki - Higher School Scientific Papers, 3, 48-57. [in Russian]. 17. Shkitska, I. Yu. (2011). Zaimennyky «ty» - «Vy» v manipuliatyvnii stratehii pozytyvu [The pronouns «ти» - «Ви» in the manipulative strategy of the positive]. Aktualni problemy slovianskoi filolohii - Current Issues in Slavic Philology. Ser. «Linhvistyka i literaturoznavstvo», XXIV, Part 1, 400-408 [in Ukrainian]. 18. Shherbinina, Yu. V. (2004). Russkij yazyk: Rechevaya agressiya i puti ee preodoleniya [Russian language: Speech aggression and ways to overcome it]. Moskva: Flinta: Nauka [in Russian]. 19. Yasakova, N. Yu. (2009). Osoblyvosti vzaiemodii katehoriinoi semantyky personalnosti ta kvantytatyvnosti. Nauk. chasopys Nats. ped. un-tu im. M. P. Drahomanova - Scientific journal of M. P. Dragomanov National Pedagogical University. Ser. 10. «Problemy hramatyky i leksykolohii ukrainskoi movy». M. Ya. Pliushch (ed.). Kyiv: Nats. ped. un-t im. M. P. Drahomanova, 5, 178-182 [in Ukrainian].

Халіман Оксана Володимирівна - кандидат філологічних наук, докторант кафедри української мови, Харківський національний педагогічний університет імені Г. С. Сковороди. Вул. Валентинівська, 2, Харків, 61168, Україна.

Tel.: +38-066-55-903-66

E-mail: khaliman_oksana@ukr.net

https://orcid.org/0000-0001-6952-0627

Khaliman Oksana Volodymyrivna - PhD in Philology, Doctoral Student, Ukrainian Language Department, H.S. Skovoroda Kharkiv National Pedagogical University. Valentynivska Str., 2, Kharkiv, 61168, Ukraine. 